\title{
Proposals of biological control of pests in greenhouse cultivation of aromatic plants in Poland and problems related to its application
}

\section{Propozycje ochrony biologicznej roślin przyprawowych przed szkodnikami w uprawach szklarniowych w Polsce i problemy związane z jej stosowaniem}

\author{
Wojciech Goszczyński ${ }^{1}$, Magdalena Lubiarz ${ }^{2 *}$, Elżbieta Cichocka ${ }^{2}$
}

\begin{abstract}
Summary
The paper presents the first ground rules for biological control of pests in greenhouse cultivation of aromatic plants. Piercing sucking insects, mainly aphids (Aphidoidea), thrips (Thysanoptera), and a single leafhopper species (Cicadomorpha) cause the greatest losses in greenhouse cultivation. Chemical protection has been banned in aromatic plant greenhouse cultivation and no insecticides have been registered so far. The data was collected during eight-year observations of the fauna of aromatic plants and attempts to regulate its numbers. The main goal of the study was to develop the procedures of biological control of pests. We investigated an application of natural enemies of herbivorous insects, that are used in other greenhouse cultivation. It was concluded that the biological methods used in other greenhouse cultivation, sometimes fail in the case of aromatic plants. In this paper we indicated methods of biological control of thrips, aphids, moths (Lepidoptera) and sciarid flies (Sciaridae) in greenhouse cultivation of aromatic plants.
\end{abstract}

Key words: biological control; aromatic plants; greenhouse cultivation; herbivorous insects; entomophages

\section{Streszczenie}

Praca prezentuje pierwsze zasady biologicznej ochrony roślin aromatycznych przed szkodnikami w uprawach szklarniowych. W uprawach tych największe szkody wyrządzają owady o kłująco-ssących narządach gębowych, głównie mszyce (Aphidoidea), wciornastki (Thysanoptera) i jeden gatunek piewika (Cicadomorpha). Jednocześnie w tych uprawach nie wolno stosować ochrony chemicznej i nie zarejestrowano dotychczas żadnego insektycydu. Dane zebrano na podstawie ośmioletnich obserwacji nad fauną roślin przyprawowych i ograniczaniem jej liczebności. Głównym celem badań było stworzenie procedur biologicznego zwalczania szkodników. Przebadano zastosowanie naturalnych wrogów owadów roślinożernych, które są używane w innych typach upraw szklarniowych. Stwierdzono, że metody biologiczne stosowane w innych uprawach pod osłonami, niekiedy zawodzą w przypadku roślin przyprawowych. W pracy zaprezentowano metody ochrony roślin aromatycznych przed wciornastkami, mszycami, motylami (Lepidoptera) i ziemiórkami (Sciaridae) w warunkach upraw szklarniowych.

Słowa kluczowe: ochrona biologiczna; rośliny przyprawowe; uprawa szklarniowa; owady roślinożerne; entomofagi

\footnotetext{
The John Paul II Catholic University of Lublin

${ }^{1}$ Department for Natural Foundations of Landscape Architecture

${ }^{2}$ Department of Environmental Protection and Landscape Preservation

Konstantynów 1H, 20-708 Lublin

*corresponding author: lubiarz@kul.pl
} 


\section{Wstęp / Introduction}

There are 16 species of aromatic plants currently cultivated in greenhouses in Poland. It was observed that they are infested by approximately 15 taxons of invertebrates (Lubiarz et al. 2013). Some aromatic species are grown from seedlings (rosemary and mint) and while others sown into small plastic pots filled with peat substrate. Their growth in greenhouses lasts between 3 and 6 weeks, and only rosemary grows longer (up to 8 weeks). When the plants reach approximately $20 \mathrm{~cm}$, they are ready to be sold. Cultivation of aromatic plants in greenhouses differs from production in ground, as there are numerous problems regarding pests and their control (Goszczyński 1998; Goszczyński and Cichocka 2004). Greenhouse production of aromatic plants in Poland lasts throughout entire year, and so development of arthropods is possible in winter season as well. Insects, such as aphids, do not overwinter in field conditions at the egg stage, but they inhabit plants growing in greenhouses in fall and they occur there until spring, or develop anholocyclic forms (Lubiarz et al. 2013). Mint plants were infested with an overwintering (anholocyclic) form of Ovatus crataegarius (Walker) that had not been observed in greenhouses so far. This aphid species was recorded in 2014 and 2015 on mint. Rosemary, and sometimes basil, mint or lemon balm were infested with a leafhopper, the species not so far observed in Poland - Eupteryx decemnotata Rey (Lubiarz and Musik 2015). Thrips (Thysanoptera), aphids (Aphidoidea) and moths (Lepidoptera) most often infested basil and mint, whereas leafhoppers (Cicadomorpha) were abundant especially on rosemary.

The presence of even a few insects on aromatic plants cultivated in greenhouses is unacceptable at the moment of selling the plants. Therefore, all plants with insects are destroyed and it results in significant financial losses. Due to the requirements not allowing occurrence of any insects or damage on aromatic plants, the main focus was on prevention means and biological control.

The main goal of the study was to develop the procedures of biological control of pests occurring in greenhouse cultivation of aromatic plants. We looked for evidence indicating the presence of herbivorous insects so it would help to evolve means to eliminate them from the cultivation. We also investigated the usefulness of natural enemies of the studied insects, that are used in other types of greenhouse cultivation.

\section{Materiały i metody / Materials and methods}

\section{Obszar badań / Area of the study}

The observations in the greenhouse near Warsaw were conducted for 8 years (2008-2015). Aromatic plants were cultivated in the greenhouses with concrete floors and equipped with mobile tables. Additionally lamps were situated approximately $2.5 \mathrm{~m}$ above the plants. The cultivation conditions were following: photoperiod: 16:8 (L:D), temperature: $22^{\circ} \mathrm{C}$, relative humidity: $80 \%$. There was continuous plants production, which is contrary to production of other edible plants such as tomatoes, bell peppers, or cucumbers when there is break in cultivation for disinfection. A total of 16 species of culinary herbs were cultivated in the greenhouses: Allium schoenoprasum L., Anethum graveolens L., Anthriscus sp., Coriandrum sativum L., Petroselinum crispum (Mill.) Fuss, Artemisia dracunculus L., Eruca sativa Mill., Melissa officinalis L., Mentha arvensis L., Mentha x piperita L., Ocimum basilicum L., Origanum majorana L., Origanum vulgare L., Salvia officinalis L., Thymus vulgaris L., Rosmarinus sp.

\section{Metody identyfikacji szkodników / Methods of pests identification}

The personnel involved in herbs production were trained for identification of pests on parts of the plant that might be infested and identifying damage symptoms as well as. This facilitated finding even individual specimens. The plants were monitored every day using the method of visual control of entire plants (Szelegiewicz 1959). Once per week yellow sticky cards were placed directly on the tables. The main goal of the monitoring was to find evidence of the presence of thrips, sciarid flies, aphids, leafhoppers and sometimes Hadeninae (adults specimens), as well as shore flies. The last group of insects does not damage the discussed plants, but they hamper the work of greenhouse employees by irritating their eyes.

The observed insects [aphids, whiteflies (Aleyrodoidea), thrips] were collected into vials with $70 \%$ ethanol in order to determine their species. Leafhoppers were collected into dry Eppendorf tube. Some of the groups required preparation of specimens - aphids, leafhoppers, thrips. Butterflies (Lepidoptera) (adult specimens) were observed on sticky cards and in light traps. The plants were examined for any damage caused by butterfly larvae. Any evidence of plant damage initiated search for larvae and especially on basil leaves. In the case of plants that showed evidence of sciarid fly larvae, the substrate was investigated for their presence under a stereo microscope.

\section{Zastosowanie metod ochrony biologicznej / The application of biological control methods}

The location of herbivorous insects on the plants was marked with special labels. The appropriate entomophages (parasitoids or predators) were introduced precisely to these sites. Only Amblyseius sp. was spread by a blower. The pots with wheat inhabited by Rhopalosiphum padi (Linnaeus) were a new element. Parasitoid Aphidius colemani Viereck reproduced on this aphid species. The pots were distributed along the tables with aromatic plants (10 pots per $1 \mathrm{ha}$ ). The aim was to maintain constant presence of parasitoids in the crops. The pots were regularly exchanged after $2-3$ weeks. The main goal was to eliminate aphids on very small aromatic plants.

Based on the observations of occurrence of pest species, their number, and visible damage, the tests were carried out using known methods of biological control in greenhouses. The selection of biological agents was based on the recommendations for other greenhouse cultivations (Malais and Ravensberg 2004). Names of species were given after Fauna Europaea (2014). 


\section{Wyniki i dyskusja / Results and discussion}

Commonly known methods of biological control were used during our study on the greenhouse cultivation of aromatic plants (Malais and Ravensberg 2004). Numerous method were examined and ineffective ones were not used anymore. In some cases it was necessary to destroy the cultivated plants. The biological control methods that were applied for years in commercial vegetable greenhouses were not always effective in greenhouses with aromatic plants production. Some methods did not proved useful e.g. in the case of greenhouse whitefly. The results of the conducted study and observation indicate that prevention and monitoring are the most important and effective methods of protection of greenhouse aromatic plant production.

\section{Proposed prevention methods:}

- cleanliness in the greenhouse (cleaning and washing), introducing only plants free from various diseases and pests; manual removal and destruction of plants, with a presence of a single pests, in the case of butterfly larvae - manual collection,

- the greenhouse should be isolated from the ground, a concrete floor is advised,

- monitoring:

- sticky roller traps (yellow and blue sticky ribbon) placed on support columns along the greenhouse $(15 \mathrm{~cm} \times 100 \mathrm{~m})$,

- additional yellow sticky cards $(25 \mathrm{~cm} \times 10 \mathrm{~cm})$ on the tables,

- light traps, as well as visual control of all plants,

- using colourful flags to mark spots, where insects were observed (e.g. aphids, thrips), in order to introduce an appropriate entomophage (predator or parasitoid) into that location.

In order to protect germinating plants (grown from seeds) or young seedlings (rosemary and mint) it is recommended to supplement the substrate, while sowing or planting of seedlings, with parasitic nematodes from the Steinernematidae family, in the amount of 0.5-0.75 million specimens per $1 \mathrm{~m}^{2}$ of the substrate (watered using a solution of water and nematodes). After moving the plants from the germination lot (after approximately 7 days) into the tables, and introduction of a mite of the Hypoaspis genus approximately 100 specimens per $1 \mathrm{~m}^{2}$ is advised in order to prevent the occurrence of sciarid flies. This species will also limit the number of thrips pupae that might be present in the substrate. The majority of parasitoids and predators used in the studied greenhouse are distributed directly onto plants, except for Amblyseius sp. which is spread by a blower.

\section{Proposed applications of entomophages against pests: Thrips nigropilosus Uzel (Thysanoptera: Thripidae)}

It was not easy to identify the species of thrips feeding on aromatic plants. However, their presence was evident from the characteristic damage (small leaf discolouration). Mint was the most infested plant. Damage of the plants was observed throughout an entire year, and thrips were the most numerous in the warmest months (June, July and August). One thrips species was recorded in the monitored greenhouses. During her study on lemon balm (M. officinalis L.) and thyme (T. vulgaris L.) cultivated in soil, Czepiel (2003) found 19 species of thrips on lemon balm and 23 - on thyme, including T. nigropilosus on both plant species. Kucharczyk et al. (2006) studied oregano (O. vulgare L.) cultivated in soil and identified 11 species of thrips, including Thrips tabaci Lindeman and T. nigropilosus. Pobożniak and Sobolewska (2011) collected thrips from 37 species of herbs cultivated also in soil. They found 12 species of thrips on sage ( $S$. officinalis L.), 5 species on chives (A. schoenoprasum L.) and 5 species on coriander (C. sativum L.). They found T. nigropilosus only on sage. T. tabaci was observed in large numbers, and there were also 25 specimens of Frankliniella occidentalis (Pergande). It should be stressed out that $T$. tabaci and $F$. occidentalis constitute a serious problem when it comes to greenhouse cultivation of various plant species (Trdan and Jenser 2003; Malais and Ravensberg 2004).

In order to reduce the number of thrips, every week a predatory mite Amblyseius cucumeris (Oudemans) was introduced to the plants in the amount of 800-1000 specimens per $1 \mathrm{~m}^{2}$. When that method did not result in decreasing the amount of adult thrips on sticky traps, a predatory true bug Orius sp. was introduced in the amount of $0.5-1$ specimens per $1 \mathrm{~m}^{2}$ (Table 1). It should be noted that the period of development of this species is quite long (more than 30 days), therefore, we do not expect this species to reproduce as regarding vegetable crops. Its presence should be perceived as an emergency method for a rapid decrease of the amount of thrips.

\section{Aphids (Hemiptera: Aphididae)}

In greenhouse cultivation of herbs 7 aphid species were found (Lubiarz et al. 2013), however this number is increasing. Some aphids can feed on these crops throughout the year: Aphis gossypii Glover, Aulacorthum solani Kaltenbach, Myzus persicae Sulzer, whereas other occur during spring and fall migrations: Aphis fabae Scopoli, Cavariella aegopodii (Scopoli), Dysaphis crataegi (Kaltenbach), Ovatus mentharius (van der Goot). The species Ovatus crataegarius (Walker) was found first time in the monitored greenhouses in 2014. Until recently it was considered holocyclic (Blackman and Eastop 2006). However it occurs during summer and remains in greenhouses during winter season. In our study $M$. persicae was observed each year for 12 months, whereas the remaining species were found only during certain summers and for shorter periods. It is estimated that the number of species overwintering in greenhouses will increase. The presence of some aphid species causes significant yield losses. At the beginning of 2015 abundant presence of $M$. persicae was one of the reasons for terminating an entire cultivation cycle of basil on one of the tables.

Aphid predators [Aphidoletes aphidimyza (Rodani)] and parasitoids (Aphidius sp.) function well when the plants are not additionally lighted. During the period of artificial lighting adult specimens of these insects spread throughout the greenhouse, and no larvae of Aphidoletes or mummies of Aphidius sp. were found. Using aphid para- 
sitoids often demands determining the aphid species. When a large aphid eg. A. solani (body length up to $3 \mathrm{~mm}$ ) appears on the crops, Aphidius ervi, should be introduced, and in the case of the small aphid eg. A gossypii (body length $0.9-1.8 \mathrm{~mm}$, in greenhouses it does not exceed
$1 \mathrm{~mm})$ - Aphidius colemani should be used. The latter parasitoid species is also effective in control of other aphid species. To prevent aphid occurrence Aphidius sp. (0.5 specimens per $1 \mathrm{~m}^{2}$ ) and $A$. aphidimyza ( 1 specimen per $1 \mathrm{~m}^{2}$ ) should be used. Also in order to reduce the

Tabela 1. Rekomendowane metody biologicznej ochrony roślin przyprawowych przed szkodnikami w uprawach szklarniowych Table 1. Recommended methods of biological control of pests in greenhouse cultivation of aromatic plants

\begin{tabular}{|c|c|c|c|}
\hline $\begin{array}{l}\text { Szkodnik } \\
\text { Pest }\end{array}$ & $\begin{array}{l}\text { Rośliny żywicielskie } \\
\text { Host plants }\end{array}$ & $\begin{array}{c}\text { Terminy } \\
\text { występowania } \\
\text { Date of occurrence }\end{array}$ & $\begin{array}{l}\text { Rekomendowane metody ochrony biologicznej } \\
\text { Recommended methods of biological control }\end{array}$ \\
\hline $\begin{array}{l}\text { Trips } \\
\text { nigropilosus }\end{array}$ & $\begin{array}{l}\text { Mentha arvensis, } \\
\text { Mentha } \mathrm{x} \text { piperita, } \\
\text { Ocimum basilicum, } \\
\text { Rosmarinus sp. }\end{array}$ & $\begin{array}{l}\text { cały rok } \\
\text { all year }\end{array}$ & $\begin{array}{l}\text { Amblyseius cucumeris }-800-1000 \text { specimens } / 1 \mathrm{~m}^{2} * \\
\text { Orius sp. }-0.5-1 \text { specimens } / 1 \mathrm{~m}^{2}\end{array}$ \\
\hline $\begin{array}{l}\text { Aphis } \\
\text { fabae }\end{array}$ & Petroselinum crispum & $\begin{array}{l}\text { maj, czerwiec, } \\
\text { wrzesień } \\
\text { May, June, } \\
\text { September }\end{array}$ & $\begin{array}{l}\text { Aphidius colemani }-0.5 \text { specimens } / 1 \mathrm{~m}^{2} \\
\text { Aphidoletes aphidimyza }-1 \text { specimen } / 1 \mathrm{~m}^{2 *} \\
\text { Chrysoperla carnea }-10-50 \text { specimens } / 1 \mathrm{~m}^{2}\end{array}$ \\
\hline $\begin{array}{l}\text { Aphis } \\
\text { gossypii }\end{array}$ & $\begin{array}{l}\text { Petroselinum crispum, } \\
\text { Rosmarinus } \mathrm{sp} .\end{array}$ & $\begin{array}{l}\text { cały rok } \\
\text { all year }\end{array}$ & $\begin{array}{l}\text { Aphidius colemani }-0.5 \text { specimens } / 1 \mathrm{~m}^{2} \\
\text { Aphidoletes aphidimyza }-1 \text { specimen } / 1 \mathrm{~m}^{2} \\
\text { Chrysoperla carnea }-10-50 \text { specimens } / 1 \mathrm{~m}^{2}\end{array}$ \\
\hline $\begin{array}{l}\text { Aulacorthum } \\
\text { solani }\end{array}$ & Ocimum basilicum & $\begin{array}{l}\text { cały rok } \\
\text { all year }\end{array}$ & $\begin{array}{l}\text { Aphidius ervi-0.5 specimens } / 1 \mathrm{~m}^{2} \\
\text { Aphidoletes aphidimyza }-1 \mathrm{specimen} / 1 \mathrm{~m}^{2} \\
\text { Chrysoperla carnea }-10-50 \text { specimens } / 1 \mathrm{~m}^{2}\end{array}$ \\
\hline $\begin{array}{l}\text { Cavariella } \\
\text { aegopodii }\end{array}$ & Anethum graveolens & $\begin{array}{l}\text { maj, czerwiec } \\
\text { May, June }\end{array}$ & $\begin{array}{l}\text { Aphidius colemani }-0.5 \text { specimens } / 1 \mathrm{~m}^{2} \\
\text { Aphidoletes aphidimyza }-1 \mathrm{specimen} / 1 \mathrm{~m}^{2} \\
\text { Chrysoperla carnea }-10-50 \text { specimens } / 1 \mathrm{~m}^{2}\end{array}$ \\
\hline $\begin{array}{l}\text { Dysaphis } \\
\text { crataegi }\end{array}$ & Petroselinum crispum & $\begin{array}{l}\text { maj, czerwiec, } \\
\text { May, June }\end{array}$ & $\begin{array}{l}\text { Aphidius colemani }-0.5 \text { specimens } / 1 \mathrm{~m}^{2} \\
\text { Aphidoletes aphidimyza }-1 \text { specimen } / 1 \mathrm{~m}^{2} \\
\text { Chrysoperla carnea }-10-50 \text { specimens } / 1 \mathrm{~m}^{2}\end{array}$ \\
\hline $\begin{array}{l}\text { Myzus } \\
\text { persicae }\end{array}$ & $\begin{array}{l}\text { Eruca sativa, } \\
\text { Mentha arvensis, } \\
\text { Mentha } \mathrm{x} \text { piperita, } \\
\text { Ocimum basilicum }\end{array}$ & $\begin{array}{l}\text { cały rok } \\
\text { all year }\end{array}$ & $\begin{array}{l}\text { Aphidius colemani }-0.5 \text { specimens } / 1 \mathrm{~m}^{2} \\
\text { Aphidoletes aphidimyza }-1 \text { specimen } / 1 \mathrm{~m}^{2} \\
\text { Chrysoperla carnea }-10-50 \text { specimens } / 1 \mathrm{~m}^{2}\end{array}$ \\
\hline $\begin{array}{l}\text { Ovatus } \\
\text { mentharius }\end{array}$ & Mentha $\mathrm{x}$ piperita & $\begin{array}{l}\text { cały rok } \\
\text { all year }\end{array}$ & $\begin{array}{l}\text { Aphidius colemani }-0.5 \text { specimens } / 1 \mathrm{~m}^{2} \\
\text { Aphidoletes aphidimyza }-1 \mathrm{specimen} / 1 \mathrm{~m}^{2} \\
\text { Chrysoperla carnea }-10-50 \text { specimens } / 1 \mathrm{~m}^{2}\end{array}$ \\
\hline $\begin{array}{l}\text { Ovatus } \\
\text { crataegarius }\end{array}$ & $\begin{array}{l}\text { Mentha arvensis, } \\
\text { Mentha } \mathrm{x} \text { piperita }\end{array}$ & $\begin{array}{l}\text { cały rok } \\
\text { all year }\end{array}$ & $\begin{array}{l}\text { Aphidius colemani }-0.5 \text { specimens } / 1 \mathrm{~m}^{2} \\
\text { Aphidoletes aphidimyza }-1 \text { specimen } / 1 \mathrm{~m}^{2} \\
\text { Chrysoperla carnea }-10-50 \text { specimens } / 1 \mathrm{~m}^{2}\end{array}$ \\
\hline $\begin{array}{l}\text { Trialeurodes } \\
\text { vaporariorum }\end{array}$ & Rosmarinus sp. & $\begin{array}{l}\text { maj, czerwiec, } \\
\text { lipiec } \\
\text { May, June, } \\
\text { July }\end{array}$ & $\begin{array}{l}\text { jak dotąd nie ma skutecznej metody ochrony biologicznej roślin } \\
\text { aromatycznych w uprawach szklarniowych } \\
\text { so far there is no effective method of biological control } \\
\text { in greenhouse cultivation of aromatic plants }\end{array}$ \\
\hline $\begin{array}{l}\text { Eupteryx } \\
\text { decemnotata }\end{array}$ & $\begin{array}{l}\text { Melissa officinalis, } \\
\text { Mentha arvensis, } \\
\text { Mentha x piperita, } \\
\text { Ocimum basilicum, } \\
\text { Rosmarinus sp. }\end{array}$ & $\begin{array}{l}\text { cały rok } \\
\text { all year }\end{array}$ & $\begin{array}{l}\text { jak dotąd nie ma skutecznej metody ochrony biologicznej roślin } \\
\text { aromatycznych w uprawach szklarniowych } \\
\text { so far there is no effective method of biological control } \\
\text { in greenhouse cultivation of aromatic plants }\end{array}$ \\
\hline $\begin{array}{l}\text { Hadeninae } \\
\text { Piętnówki } \\
\text { Podrodzina } \\
\text { Subfamily }\end{array}$ & $\begin{array}{l}\text { Mentha arvensis, } \\
\text { Mentha } \mathrm{x} \text { piperita, } \\
\text { Ocimum basilicum }\end{array}$ & $\begin{array}{l}\text { lipiec, sierpień } \\
\text { July, August }\end{array}$ & $\begin{array}{l}\text { Bacillus thuringiensis - zawiesina wodna } 0,6 \mathrm{dm}^{3} / 10 \mathrm{~m}^{2} \\
\text { Bacillus thuringiensis - water suspension } 0.6 \mathrm{dm}^{3} / 10 \mathrm{~m}^{2}\end{array}$ \\
\hline $\begin{array}{l}\text { Sciaridae } \\
\text { Ziemiórkowate } \\
\text { Rodzina } \\
\text { Family }\end{array}$ & $\begin{array}{l}\text { wszystkie uprawiane rośliny } \\
\text { all cultivated plants }\end{array}$ & $\begin{array}{l}\text { cały rok } \\
\text { all year }\end{array}$ & $\begin{array}{l}\text { Steinernema feltiae }-0,5-0,75 \text { miliona osobników } / 1 \mathrm{~m}^{2} \\
\text { Steinernema feltiae }-0.5-0.75 \text { million specimens } / 1 \mathrm{~m}^{2}\end{array}$ \\
\hline
\end{tabular}

*osobników $/ 1 \mathrm{~m}^{2}$, osobnik $/ 1 \mathrm{~m}^{2}$ - specimens $/ 1 \mathrm{~m}^{2}$, specimen $/ 1 \mathrm{~m}^{2}$ 
number of aphids, larvae (first larval stage) of Chrysoperla carnea (Stephens) were introduced throughout the year with satisfactory success. We recommend 10-50 specimens per $1 \mathrm{~m}^{2}$ in the locations where aphids occurred (Table 1). However, it should be stressed that lacewing larvae experience problems with migrating from one row of plants to another, since they are located approximately $12 \mathrm{~cm}$ apart. Larvae migration is virtually impossible, especially when aromatic plants are still small and their leaves are not in contact with each other, which makes it impossible for them to move from one plant to another.

\section{Trialeurodes vaporariorum (Westwood) (Hemiptera:} $\underline{\text { Aleyrodidae) }}$

Greenhouse whitefly appeared only once in 2010 and it was numerous only on rosemary. Encarsia formosa Gahan (10 specimens per $1 \mathrm{~m}^{2}$ in the areas where whiteflies occured) and Amblyseius swirskii Athias-Henriot (10 specimens per $1 \mathrm{~m}^{2}$ ) were applied then. However, introducing these entomophages did not bring the expected results and the infested plants had to be destroyed (Table 1). In addition, abundant occurrences of this whitefly species were accompanied by large numbers of Aphis gossypii aphids (difficult for biological control), which was one of the reasons of destroying the infested plants.

\section{Eupteryx decemnotata Rey (Hemiptera: Cicadellidae)}

Ligurian leafhopper is a new species occurring in Poland (Lubiarz and Musik 2015). It is observed in large population on rosemary, and less on mint, basil, and lemon balm. Ligurian leafhopper was the most numerous in 2014. It was particularly well-developed in mother plantations of rosemary and one mother plantation had to be destroyed. The feeding of this species causes serious injuries and the infested leaves turn yellow, then wither and fall. Ligurian leafhopper adult specimens and larvae were removed from plants using a vacuum cleaner. Adult specimens of this species were observed on yellow sticky cards. Biological control of this species has not been carried out so far (Table 1). The life cycle of this leafhopper species has not been fully studied yet. This species requires urgent study, since during the years of its occurrence it is immensely numerous. According to Nickel and Holzinger (2006) two to three generations of this species can be observed in field and it may be even more abundant in the southern parts of Europe. In Central Europe adult specimens are observed from June to November, whereas in Southern Europe the first specimens were noted as early as in April (Nickel and Holzinger 2006).

\section{Hadeninae larvae (Lepidoptera: Noctuidae)}

In June adult specimens of this butterfly were captured using light traps. Every year in July and August from a few to dozens plants with individual larvae were found. The larvae were destroyed manually. In the case of more numerous occurrences Bacillus thuringiensis Berliner can be introduced to the infested sites (Konecka et al. 2011). This bacterium should be used in accordance with the recommendations of the manufacturer, available on the product label. Usually it is the water suspension $0.6 \mathrm{dm}^{3}$ per $10 \mathrm{~m}^{2}$ (Table 1 ).

\section{Sciaridae (Diptera)}

Adult specimens of sciarid flies were observed every year of the study. Dozens of adult specimens were caught per $10 \mathrm{~cm}$ of yellow sticky roller traps. An excess of the larvae of these flies in the soil leads to damage of the sprouts of aromatic plants. In order to prevent their excessive development, nematodes Steinernema feltiae (Filipjev) are used prophylactically while sowing, in the amount of approximately $0.5-0.75$ million specimens per $1 \mathrm{~m}^{2}$ of the substrate (Table 1). Nematodes proved to be effective and no damage to the plants was recorded.

\section{Wnioski / Conclusions}

1. We show recommendations regarding methods of biological control for aromatic plants grown in greenhouses. This is the first attempt of establishing ground rules of protecting crops of aromatic plants in greenhouse cultivation. The authors are aware that subsequent species of herbivorous arthropods appeared, which may eventually lead to adjusting protection methods. In addition, introduction of new varieties or plant species will result in modification of the program, since other insects may appear.

2. The greatest problem in the case of the discussed cultivation is biological control of aphids. Due to a short period of generation development, as well as quite high fertility, aphids can develop on average of 2 or 3 generations in these types of cultivation within a single cultivation cycle, forming large populations. We suggest application of $A$. aphidimyza and Aphidius sp. when the plants are small, and we recommend using larvae of Chrysoperla on mature plants.

3. Using biological methods prevents insects from spreading in the greenhouse, however, the consumer of aromatic plants most probably will not tolerate plants with aphid mummies, or larvae of Aphidoletes or Chrysoperla on the leaves. Therefore, herbivorous insects should be eliminated on young plants.

4. Yearlong protected cultivation of aromatic plants is difficult and demands well-trained personnel in order to minimise financial losses caused by the necessity of destroying plants infested with herbivores.

\section{Podziękowanie / Acknowledgements}

Authors would like to thank heartily professor Halina Kucharczyk (Maria Curie-Skłodowska University in Lublin) for identifying the thrips species. 


\section{Literatura / References}

Blackman R.L., Eastop V.F. 2006. Aphids on the World's Herbaceous Plants and Shrubs. Vol. 1 and 2. John Wiley \& Sons, Chichester, $1439 \mathrm{pp}$.

Czepiel K. 2003. Thrips (Thysanoptera, Insecta) collected on Thymus vulgaris and Melissa officinalis in Fajslawice (The Lublin Region). Acta Agrophysica 1 (1): 39-45.

Fauna Europaea. 2014. Fauna Europea - all European animal species on the web. Biodiversity Data Journal 2: e4034. www.faunaeur. org/distribution.php [Accessed: 22.01.2016].

Goszczyński W. 1998. Hemiptera infesting umbelliferous and spice medicinal plants. p. 31-34. In: "Monograph Aphids and other Homopterous Insects" Vol. 6. (E. Cichocka, W. Goszczyński, K. Wiech, eds.). Warsaw Agricultural Univeristy, Warsaw, 145 pp.

Goszczyński W., Cichocka E. 2004. Aphids on selected seasoning and medicinal herbs. p. 15-22. In: "Monograph Aphids and other Hemipterous Insects" Vol. 10. (G. Łabanowski, ed.). Instytut Sadownictwa i Kwiaciarstwa, Rogów - Skierniewice, 156 pp.

Konecka E., Kaznowski A., Baranek J. 2011. Wykorzystanie bakterii Bacillus thuringiensis do produkcji bioinsektycydów. [The use of Bacillus thuringiensis in the production bio-insecticides]. Postępy Mikrobiologii 50 (4): 303-311.

Kucharczyk H., Setniewska M., Legutowska H. 2006. Zróżnicowanie fauny wciornastków (Thysanoptera) na roślinach zielarskich w rejonie warszawskim. [The diversity of thrips fauna (Thysanoptera) on herbs in the Warsaw region]. Progress in Plant Protection/Postępy w Ochronie Roślin 46 (2): 429-432.

Lubiarz M., Goszczyński W., Cichocka E. 2013. Invertebrates inhabiting culinary herbs grown under cover. Journal of Plant Protection Research 53 (4): 333-337.

Lubiarz M., Musik K. 2015. First record of the Ligurian leafhopper, Eupteryx decemnotata Rey 1891 (Cicadomorpha, Cicadellidae) in Poland - an important pest of herbs. Journal of Plant Protection Research 55 (3): 324-326.

Malais M.H., Ravensberg W.J. 2004. Knowing and Recognizing: the Biology of Glasshouse Pests and Their Natural Enemies. Koppert B.V. and Reed Business Information, The Netherlands, $288 \mathrm{pp}$.

Nickel H., Holzinger W.E. 2006. Rapid range expansion of Ligurian leafhopper, Eupteryx decemnotata Rey, 1891 (Hemiptera: Cicadellidae), a potential pest of garden and greenhouse herbs, in Europe. Russian Entomological Journal 15 (3): 57-63.

Pobożniak M., Sobolewska A. 2011. Biodiversity of thrips species (Thysanoptera) on flowering herbs in Cracow, Poland. Journal of Plant Protection Research 51 (4): 393-398.

Szelegiewicz H. 1959. Jak zbierać i konserwować mszyce dla celów naukowych? [How to collect and conserve aphids for research purposes?]. Polskie Pismo Entomologiczne, Seria B 1-2 (13-14): 77-80.

Trdan S., Jenser G. 2003. Monitoring of western flower thrips (Frankliniella occidentalis Pergande) in the vicinity of greenhouses in different climatic conditions in Slovenia. IOBC-WPRS Bulletin 26 (3): 25-31. 